\title{
ANALISIS SEMANTIK UMUM : PEMBERITAAN TERORIS "IMAGE ISLAM'PADA MAJALAH TEMPO DAN SABILI
}

\author{
Rahma Hidayati \\ Program Studi Ilmu Komunikasi, Universitas Teuku Umar \\ Email: rahmahidayati33@yahoo.com
}

\begin{abstract}
Abstrack
People tend to misconceive the word terrorist thereby equating with Islam. There are several labels and inferences given on the word terrorist such as radical, militants, extreme etc. Thus this study was conducted to analyze the image of Islam and terrorists in Tempo and Sabili magazines. Qualitative methodology was used to conduct this research, namely, content analysis. Data obtained were analyzed using sub-categories trikotomi from the General Semantic perspectives forwarded by Rajib Ab Ghani (1984). Both Tempo and Sabili tend to use unsourced inferences in their report.
\end{abstract}

Keywords: Image of Islam, General Semantic Analysis

\section{PENDAHULUAN}

Menurut Martin \& Chaudary (1983) banyak faktor yang harus diperhatikan dalam pemberitaan seperti pemikiran wartawan, editor dalam melihat apa yang diinginkan oleh audien, sifat media itu sendiri (pertimbangan penerbit dan pemilik terhadap misi media), budaya dan ideologi. Tentunya masalah-masalah ini akan membawa pengaruh terhadap pemberitaan yang diberikan kepada masyarakat.

Arpan (1964) menyatakan bahwa banyak wartawan tidak begitu memberi perhatian yang lebih terhadap bahasa. Mereka berfikir bahwa semua yang dilakukan dapat mendatangkan informasi, mereka hanya menulis siapa, apa, kapan, dimana dan mengapa, padahal mereka tahu bahwa ada cara perbedaan yang besar dalam menulis. Oleh karena itu wartawan harus teliti dan cermat dalam melaporkan pemberitaannya.

Hal ini juga serupa juga dikatakan oleh Faridah (2004) dengan pemilihan bahasa dan istilah yang tepat serta pengekalan nada dan orientasi asal sebuah berita dalam judulnya, surat kabar dapat meningkatkan objektivitas dalam laporan berita ini karena bahasa berita adalah dibawah kawalan wartawan itu sendiri.Jadi wartawan sendiri yang mencipta bahasa yang akan digunakan dalam pemberitaan terhadap isu.

Isu teroris yang diberitakan dalam media massa terkadang cenderung menggambarkan Islam sebagai pihak yang bertanggung jawab atas kejahatan yang terjadi. Realitas ini tidak terlepas dari pihak media yang telah mengkonstruksi isu teroris yang terjadi selama ini.Isu tersebut bisa jadi dalam bentuk negatif atau positif, sehingga berbagai anggapan yang timbul di masyarakat merupakan hasil dari pada olahan media terhadap pemberitaan yang dipaparkan.

Fenomena yang terjadi dikalangan masyarakat adalah perbedaan makna kata "teroris" yang diberitakan oleh media. Sebagian masyarakat menganggap bahwa teroris adalah penjahat dan sebagian lagi menganggap bahwacara yang disebut "teroris"adalah berjihad di jalan Allah. Hal ini serupa dengan apa yang dikatakan oleh Heri Budiyanto (2006) para pelaku bom Bali I dan II serta Bom Kuningan mengaku bahwa apa yang mereka lakukan adalah untuk menegakkan kebenaran dan membela ajaran Islam. Sedangkan Nasir Abbas (2009) menyebutkan bahwa pandangan jihad Imam Samudera merupakan pandangan yang 'sesat' dan 'menyesatkan'.Masyarakat yang kurang 
memahami akan meyakini pandangan yang salah, dengan menyamakan jihad dengan terorisme. Sebagian masyarakat yang tidak mengerti ajaran Islam, Islam sering dilabelkan sebagai agama teroris. Kekeliruan ini dapat disebabkan karena kurangnya pemahaman masyarakat akan Islam. Tetapi tidak menutup kemungkinan karena sebagian Muslim justru melakukan jihad melalui aksi-aksi terorisme.

Dari pernyataan tersebut maka dapat dilihat bahwa, terdapat perbedaan dalam memaknai kata teroris, maka dengan penggunaan bahasa yang tepat akan menghindari kesalahan persepsi terhadap masalah tersebut.

\section{METODE PENELITIAN}

Kajian ini menggunakan metode kualitatif, yaitu melalui analisis kandungan dengan menggunakan kaedah sub-sub kategori trikotomi dari sudut kaedah semantik umum yang diperkenalkan oleh Mohd Rajib Ab. Ghani (1984). Menurut Watt dan Berg (dalam Adnan, 1999) sebagian besar program kajian analisis kandungan berkisar pada usaha menyelidiki ciri-ciri semantik atau persoalan makna termasuk ciri-ciri kontekstual dan hubungannya dengan berbagai fenomena sosial yang ada. Dengan kata lain dapat dipahami bahwa semantik sebagai ilmu yang mempelajari mengenai makna sangat sesuai jika menggunakan teknik analisis kandungan.

\section{Pemilihan Bahan Kajian}

Adapun edisi yang akan dikaji pada majalah Tempo adalah:

1. Edisi 21 Maret 2010 dalam judul "matikah Teror", "Pria Berjenggot di bilik Sembilan", "Agar Serambi menjadi Moindanao", dan "Dari Pemalang ke Pamulang", Teroris: Pelajaran dari Aceh".

2. Edisi 28 Maret 2010 dalam judul " Angkatan Baru Penebar Teror", "Bukan Teror Sarung dan Peci", "Eksekusi", dan "Teli Temali di Seantero Negeri".

3. Edisi 3 Oktober 2010 dalam judul "Di Balik Penyerbuan Densus 88”," Aksi Jaringan Sang Gubernur Militer."Serangan terbuka pasukan Tholut", "Alah koordinasi Karena Rahasia".

Sementara edisi dalam majalah Sabili adalah:

1. Edisi 18 Th. XVII 1 April 2010/16 Rabiul Akhir 1431, dalam judul “ Jejak Dulmatin dan Umar Patek dari Pamulang hingga Pemalang", "Menelusuri jejak Umar Patek", "Manusi 10 juta Dollar", dan "Dejihadisasi Ala Amerika".

2. Edisi 19 Th. XVII 15 April 2010/30 Rabiul Akhir, dalam judul "Membedah Ideologi DPO, "Panggilan Thaghud"," Siapa Teroris Siapa Mujahid", Memancing Jaring Menjerat Aktivis", "Extrajudical Killing", "Meredam Teror Menyentuh Buah Hati".

3. Edisi 23 Th. XVII 10 Jun 2010/ Jumadil akhir 1431, dalam judul "Salah Langkah Penanganan Terorisme", dan "Rehabilitasi Aktivis Islam".

4. Edisi 24 Th. XVII 24 Jun 2010/ 11 Rajab 1431, dalam judul "Menguak Kejanggalan Kasus Terorisme”, "Aparat Ingin Mengaitkan Saya”.

5. Edisi 6 Th. XVIII 4 November 2010/ 27 Dzulqaidah 1431, dalam judul "Audit Densus 88"."Dana Asing Densus 88".

6. Edisi 14 Th. XVIII 3 Maret 2011/27 Safar 1432, dalam judul "Episode Ketiga Pengadilan ABB", "Menyulitkan dan Berlebihan" dan Pemerintah Jangan Mau Didikte Asing”. 


\section{KERANGKA TEORI}

\section{Semantik Umum}

Semantik umum pertama kali diperkenalkan oleh Alfred Korzybski (1959) menurutnya semantik umum adalah kajian mengenai proses penilaian manusia khususnya pada hubungan tanda dan simbol termasuk bahasa. Menurutnya pula semantik umum mempelajari bagaimana manusia menyimpan pengalaman dan pengetahuan melalui fungsi bahasa sebagai penghubung waktu; bahasa mengikat waktu dan bahasa mengikat umur manusia bersama. Manusia dapat melakukan generalisasi dan simbolisasi pengalaman dan mewariskannya dari generasi ke generasi. Ia menggunakan metode psikomatematikal sebagai landasan kajian mengenai manusia. Sehingga ia menggunakan istilah semantik umum untuk merujuk kepada pendekatan baru dalam kajian mengenai manusia dalam fungsi bahasa yang khas untuk menunjukkan satu metode. Ia berpendapat bahwa dengan ilmu manusia akan sampai pada keselarasan batin dan jasmani masyarakat seutuhnya (Jos, 1990).

Menurut Mohd Rajib dan Faridah (dalam Mohd Rajib Ab Ghani, 2000) konsep semantik umum merupakan kaedah modern untuk menilai bahasa dalam tiga proses yang berbeda yaitu pemilihan bahasa, pemikiran dan tindakan manusia. Maka jika diperhatikan ketiga elemen ini saling berhubungan antara satu dengan yang lain. Korzybski juga berpendapat bahwa semantik umum merupakan satu reaksi kepada filsafat Aristoteles. Oleh karena itu ia menyebutkan bahwa aliran filsafat diperkenalkan oleh dirinya adalah bersifat nonaristoteles, karena tidak menggunakan filsafat Aristoteles.

Menurut Stuart Chase (1954) ada tiga tujuan dari pada Semantik Umum yaitu: pertama, untuk membantu manusia dalam menilai kata-kata, sebagaimana diketahui bahwa lingkungan kita akan berkembang lebih kompleks, sehingga memerlukan ketelitian untuk menafsirkan kata-kata tersebut. Kedua, untuk meningkatkan komunikasi antara satu dengan yang lain, termasuk antara kelompok dari berbagai golongan. Ketiga adalah untuk membantu membersihkan penyakit mental.Ketiga komponen ini menunjukkan bahwa semantik umum dapat membantu manusia dalam menginterpretasi makna yang ada dalam masyarakat.

Untuk menghindari diri dari kekeliruan dan kemungkinan dalam kesalahan bahasa, S.I Hayakawa mengkaji tiga kategori pernyataan yang sering membawa kontroversi dalam proses mencapai objektivitas dalam penulisan iatu: pernyataan laporan, pernyataan tanggapan dan pernyataan hukuman. Menurut Hayakawa (1940), pernyataan laporan adalah pernyataan yang dapat di verifikasi atau yang dapat disahkan. Bahasa laporan adalah bahasa sains yang akurat sehingga dapat diterima oleh orang lain seperti $2 \times 2$ adalah 4 . Sehingga pernyataan laporan ini sulit untuk dibantahkan karena sesuai dengan fakta yang sebenarnya. Bahasa laporan haruslah berdasarkan pengalaman orang pertama dalam menyaksikan sebuah kejadian.

Menurut Hayakawa pula tanggapan dan menyimpulkan penting dalam kehidupan manusia.Namun kadangkala wartawan mengunakan tanggapan secara berlainan.Dalam penulisan berita dan judul berita, tanggapan mampu mengekang seluruh fakta karena bahasa wartawan yang dicetak dan mengandung unsur tanggapan akan diterima sebagai suatu fakta yang nyata. Pernyataan tanggapan seringkali sulit disahkan karena memang sifatnya begitu. Setiap manusia mempunyai pemikirannya tentang "sesuatu" dalam dunia luar yang mana penerimaan pada orang lain adalah tidak perlu. Untuk menghindari diri dari membuat tanggapan adalah dengan tidak menebak atau coba meramal apa yang terlintas dalam pikiran orang lain (Faridah Ibrahim, 2004). 
Menurut Hayakawa (1954) Pernyataan hukuman dapat terjadi jika penulis menggambarkan ekspresinya dalam bentuk persetujuan atau tidak setujunya atas suatu perkara atau objek.Faridah (2004) menambahkan bahwapernyataan hukuman ada apabila mencampuradukkan sentimen dan emosi mereka dalam menghasilkan sesuatu berita dan judul berita.Pernyataan hukuman ini ada jika timbulnya persetujuan atau tidak setuju seseorang terhadap sesuatu yang sedang dibicarakan.Oleh sebab pernyataan hukuman tidak objektif karena banyak mengandung elemen nilai dan pemikiran di bawah sadar manusia, sehingga pernyataan ini mampu menimbulkan elemen bias.

Selain itu juga Korzybski (dalam Hayakawa, 1954) menyebutkan bahwa untuk memudahkan transisi orientasi dari Aristotelian kepada bukan Aristotelian. Ia menawarkan satu beberapa peraturan, yaitu, pertama, penggunaan indeks. Perkataan menyatukan individu-individu yang unik dibawah satu nama yang umum. Nama-nama ini dapat memberikan identitas palsu kepada fakta dan peristiwa tersebut. implikasi ini berlaku ketika diterjemahkan kedalam hasil tingkahlaku sebagai reaksi serupa dengan semua individu yang dapat diberikan nama yang sama.

Kedua, penggunaan tanggal. Heraclitus pernah menyebutkan bahwa "kamu tidak akan melangkah pada dua kali pada sungai yang sama" dunia dan segala isinya adalah dalam proses perubahan. Tetapi banyak corak tingkahlaku, pendapat dan kepercayaan mempunyai kecenderungan untuk tinggal tetap dan statik meskipun timbulnya perubahan pada keadaan. Semua istilah, pernyataan, pendapat dan kepercayaan harus diberi tanggal. Prinsip ini juga mengira fakta atau individu adalah berbeda dalam keadaan yang berbeda. Usaha meletakkan tanggal bagi semua istilah dan pernyataan ketika melakukan penerjemahan kedalam corak reaksi, akan membuat kekakuan dari tingkahlaku yang mustahil untuk berfikir dan bartindak.

Ketiga,ungkapan "et cetera".Semua pernyataan perlu disertai dengan ungkapan "et cetera" untuk mengingatkan salah satu premis "map" tidak mewakili semua "territory" bahwa tidak ada pernyataan mengenai objek atau peristiwa didunia nyata yang boleh bersifat pasti.Keempat, ungkapan "is" untuk pengidentifikasian. Perintah umum seperti "call a spade a spade" mempunyai efek yang sangat keliru. Untuk mewaspadai penggunaan "is" adalah untuk menjaga terhadap kata-kata yang mengelirukan antara keterangan verbal dengan peristiwa sebenar.

Kelima, penggunaan tanda kutip.Banyak istilah dalam bahasa sehari-hari mempunyai implikasi pra-saintifik, metafisikal, dan kasustrukturan.Namun kosa kata biasanya sering tidak mengandung istilah yang lebih baik. Misalnya "pikiran"," bangsa," "substansi," "sama" dan sebagainya. Harus digunakan dalam tanda kutip sebagai peringatan bahwa perkataan-perkataan tersebut tidak boleh dipercaya.

Keenam, penggunaan tanda strip. Bahasa lisan tradisional biasanya memisahkan banyak hal yang sebenarnya tidak dapat dipisahkan. Sebuah revolusi dalam fisik telah dilakukan dengan demonstrasi enstain bahwa ruang dan masa tidak boleh dianggap terpisah dan bahwa orang harus berfikir dalam ruang-masa. Sama halnya, obat psyco-somatic gangguan fisik dan mental tidak dapat dipisahkan,bio-physic,menawarkan kaedah umum untuk menangani sekaligus dengan living dan non-living. Penggunaan istilah ditulis dengan tanda strip seperti (psycho-biological, socio-cultural, geo-political) sehingga meningkatkan kesadaran akan hubungan daripada kejadian-kejadian yang diabaikan oleh bahasa tradisional.

Berdasarkan falsafah semantik umum, Korzybski menekan pentingnya ketepatan dan kemiripan dalam penggunaan bahasa. Menurut Mohd Rajib (dalam Mohd Rajib, 2000) orientasi bahasa bukan Aristotalian telah menggambarkan adanya kekalutan atas perilaku bahasa yang terjadi pada masa ini. Perkataan-perkataan yang digunakan oleh seseorang sering tidak mewakili makna sebenarnya. Menurut Mohd Rajib (2000) 
kadangkala apabila kita membuat klasifikasi tentang orang atau sesuatu perkara, kita menggunakan perkataan-perkataan yang bersifat mujarad (abstrak) misalnya 'kebebasan', 'demokrasi', radikal', 'kecemerlangan', 'kekerasan', dan sebagainya. Contoh-contoh ini sebenarnya tidak membawa makna yang mutlak atau yang sebenarnya. Seperti kajian yang sedang dijalankan, menggunakan perkataan "teroris" juga merupakan istilah yang bersifat mujarad karena tidak dapat memberikan arti yang sebenarnya.

\section{HASIL DAN PEMBAHASAN}

\section{Image Islam dalam Penggunaan Semantik Umum pada Majalah Tempo}

Pada penggunaan tanda kutip ada beberapa kata yang digunakan oleh majalah Tempo seperti: 'karya', merujuk pada hasil aktivitas Dulmatin sebagai individu yang dianggap sebagai teroris. 'Jalur keras' merujuk pada jalan yang ditempuh oleh para aktivitass Islam namun dianggap sebagai teroris. 'Jawara' merujuk kepada aktivitas Azahari dan Noor Din M. Top dalam hal teroris yang dilabelkan sebagai teroris yang unggul. 'Meramu', merujuk pada perbuatan Dulmatin sebagai pembuat bom. 'Bermain' merujuk pada Jamaah Ansarut Tauhid yang juga ikut telibat dalam pelatihan tentara di Aceh. 'Perjuangan' merujuk pada aktivitas tentara di Aceh yang berusaha mencari dana untuk aktivitas mereka. Penggunaan tanda kutip seperti ini merupakan masalah penting sebagai usaha wartawan untuk memberitahukan bahwa perkataan tersebut tidak boleh diterima semuanya. Namun penggunaan tanda kutip ini akan memberikan image negatif kepada aktivis-aktivis Islam terkait dengan isu teroris di Indonesia.

Pada penggunaan tanggal, Tempo juga menggunakan beberapa istilah seperti Bom Bali 2002 dan Bom Bali 2005. Penggunaan tanggal untuk menjelaskan kejadian yang berlainan pada waktu yang berlainan pula. Ahli falsafah Greek Heraclitus berkata (dalam Mohd Rajib, 2000) "man cannot step into the same river" ini bermaksud bahwa semua kejadian berubah dari masa ke masa. Contoh ini memberikan pemahaman bahwa Bom Bali yang terjadi di Indonesia juga terjadi pada tahun yang berlainan.

Selanjutnya, ungkapan et cetera, istilah ini digunakan untuk menjelaskan bahwa tidak sembarang pernyataan yang pasti untuk satu-satu perkara atau objek. Seperti Tempo memberi contoh 'Dulmatin dkk sudah merekrut pasukan berani mati' dkk merujuk pada dan kawan-kawan, ini bermakna bahwa tidak hanya Dulmatin yang mengumpulkan pasukan berani mati tetapi juga ada nama-nama lain yang tidak disebutkan. Penggunaan etc seperti ini akan memberi image negatif kepada Islam terkait dengan isu terorisme di Indonesia, karena adanya nama-nama lain yang tidak disebutkan sehingga akan menambah rangkaian para teroris yang dimaksud.

Tempo juga menggunakan istilah abstrak dalam pemberitaannya seperti: militan, ekstrimis, radikal, Islam garis keras, kelompok pengajian garis keras, kelompok militan berbasis pesantren, pasukan berani mati, kelompok militan, dan ideologi garis keras. Semua contoh yang terdapat dalam majalah ini menunjukkan bahwa wartawan masih menggunakan istilah mujarad (abstrak) tahap tinggi sebagai bentuk ketidaktahuan wartawan pada makna kata tersebut. Penggunaan istilah ini dapat menyebabkan kekeliruan kepada pembaca karena tidak ada makna sebenarnya atas istilah yang digunakan. Dari penggunaan istilah ini menunjukkan bahwa Tempo masih menggunakan label yang negatif terhadap Islam terkait dengan isu terorisme yang terjadi di Indonesia.

Dalam aspek pengidentifikasian tidak wajar (undueidentification) yaitu istilah yang digunakan untuk menyamakan semua kejadian atau objek dalam melaporkan sebuah berita. Dalam pemberitaanya Tempo masih menggunakan tahap ini misalnya pada contoh 'semua pelaku peledakan bom yang disebut-sebut terkait dengan Jamaah Islamiyah' dalam hal ini 
wartawan telah melakukan pengidentifikasian manusia sebagai sama yang memberitakan bahwa seolah-olah semua yang terlibat dalam pengeboman juga terkait dengan jamaah Islamiyah. Berita ini akan memberikan kasusan negatif kepada Jamaah Islamiyah sebagai organisasi Islam. Kemudian kata yang menyatakan bahwa 'polisi itu kafir yang darahnya halal' Pernyataan ini akan menambah image negatif kepada Islam, karena dibolehkan untuk membunuh. Pengidentifikasian tidak wajar terdapat pada 'polisi itu kafir' meskipun yang dimaksud kafir menurut mereka adalah polisi yang beragama Islam yang telah menangkap dan membunuh para kelompok yang terlibat dalam aktivitas jihad. Namun pernyataan ini telah membuat manusia itu sama yaitu semua polisi kafir.

Dalam penggunaan sub-sub trikotomi pula Tempo cenderung menggunakan pernyataan tanggapan tidak bersumber, yang merupakan tanggapan atau kesimpulan wartawan dalam menuliskan sesebuah berita. Hal ini dapat dilihat pada pernyataan tanggapan wartawan dalam melabelkan kata teroris kepada Dulmatin. Tanggapan bahwa kelompok yang berlatih di Aceh sebagai kelompok militan yang telah mendapatkan tempat baru untuk pelatihan mereka dan tanggapan bahwa Majelis Mujahidin Indonesia juga terlibat dalam pelatihan di Aceh. Wartawan juga membuat kesimpulan bahwa ideologi perjuangan mereka diajarkan bahwa merampok dan membunuh adalah sah. Pada kasus sofyan Tsauri Tempo memberitakan bahwa Soyfan adalah Polisi yang telah keluar dari pekerjaannya dan masuk kedalam kemah pelatihan tentara di Aceh sebagai pelatih tentara, sehingga pihak polisi menganggapnya sebagai teroris. Pernyataan tanggapan tidak bersumber ini cenderung negatif kepada image Islam terkait dengan isu terorisme yang terjadi di Indonesia.

Pada pernyataan laporan bersumber seperti POLRI menyatakan bahwa Dulmatin sebagai tersangka teroris dan mereka akan merampok. Pernyataan ini memberikan Image negatif kepada Islam terkait dengan isu terorisme yang terjadi di Indonesia. Sekretaris FPI, Atthahiri menyebutkan mereka merasa terpanggil untuk berjihad disana, ini menggambarkan apa yang mereka lakukan adalah sesuatu yang bersifat kemanusiaan untuk membantu sesama muslim.

Pada pernyataan tanggapan bersumber, Tempo cenderung menggunakan sumber berita yang diambil dari beberapa pihak yaitu: POLRI yang menyatakan bahwa Dulmatin sebagai tersangka teroris. Sidney John selaku pengamat teroris dan penasehat International Crisis group yang menyatakan tidak benar jika berfikir bahwa ancaman teroris berkurang dengan kematian Dulmatin. Selanjutnya, Noor Huda Ismail sebagai Ketua Prasasti Perdamaian di Indonesia yang menyatakan pengeboman yang terjadi di Keduataan Australia berasal dari kelompok Darul Islam di Banten. Dari pernyataan tanggapan bersumber ini, dapat dilihat bahwa sumber-sumber pemberitaan Tempo adalah mereka yang tidak memihak kepada Islam, maka wajar saja kalau pendapat mereka cenderung negatif kepada aktivis-aktivis Islam yang ingin mendirikan syariat Islam dan masalah jihad.

Pada pernyataan hukuman bersumber, Sidney John menyebutkan 'kemampuan mengelak dari pasukan keamanan ini menjadi tanda pemimpin teroris yang baik, pemimpin teroris yang baik bermaksud menyebutkan Usamah Bin Ladin sebagai individu yang susah dicari oleh pihak yang ingin membunuhnya, karena dia dianggap sebagai orang yang sangat berpengaruh dalam teroris dunia. Disamping itu, Tempo juga menggunakan pernyataan hukuman tidak bersumber yang dibuat berdasarkan persetujuan wartawan terhadap Dulmatin dengan kalimat 'puncak kejahatan Dulmatin dilakukan di Bali'. Pada pernyataan ini wartawan telah melabelkan kata jahat kepada Dulmatin. Semua contoh pernyataan tersebut telah memberikan image negatif kepada Usamah dan Dulmatin selaku orang Islam. 


\section{Image Islam dalam Penggunaan Semantik Umum pada Majalah Sabili}

Dalam penggunaan tanda kutip seperti: 'jihad' tanda kutip ini merujuk pada Amrozi, Ali Ghufron, Imam Samudra dan Dulmatin yang oleh polisi di cap teroris. Pada berita ini wartawan coba menggunakan tanda kutip ini untuk melabelkan jihad pada keempat orang tersebut. Selanjutnya 'ilmu nakut-nakuti' merujuk pada perkataan Munarman yang menyatakan bahwa selama ini isu terorisme hanyalah rancangan pihak polisi untuk membuat resah masyarakat. Namun penggunaan tanda kutip ini digunakan wartawan sebagai peringatan bahwa perkataan tersebut tidak harus diterima bulat-bulat.Dari penggunaaan tanda kutip ini menunjukkan bahwa wujud image yang positif bagi mereka yang selama ini dianggap sebagai teroris.

Pada penggunaan tanggal, dapat dilihat pada contoh Bom Bali 2002. Penggunaan tanggal ini berguna untuk menyatakan bahwa sebuah kejadian adalah berlainan dalam waktu yang berlainan pula, dengan kata lain sebuah kejadian bisa berubah dari waktu ke waktu. Sebagaimana diketahui Bom Bali yang terjadi di Indonesia selain terjadi pada tahun 2002 juga terjadi pada tahun 2005. Sabili juga menggunakan indeks, seperti contoh Bom Bali I. penggunaan indeks I menunjukkan bahwa adanya kesamaan kejadian yang disatukan dibawah satu nama umum. Sebagaimana diketahui bahwa Bom Bali yang terjadi di Indonesia terjadi pada tahun 2002 dinamakan dengan Bom Bali I dan Bom Bali pada tahun 2005 dinamakan dengan Bom Bali II.

Dalam ungkapan etc, seperti contoh 'dulu Majelis Mujahid Indonesia, kini Jamah Ansharut Tauhid yang diincar. Sementara kelompok lain semisal Laskar Kristus, Geng Coker, dan lain-lain dibiarkan saja'. Pernyataan ini dinyatakan oleh Sapto yang juga adalah penulis buku Kontra Terorisme: Dilema Indonesia Era Transisi. 'Dan lain-lain' merujuk kepada etc, ini menunjukkan bahwa masih ada nama lain dari kelompok agama ini, namun tidak disebutkan. Dari ungkapan ini memberikan Image yang positif kepada Islam terkait terorisme yang selalu diarahkan kepada Islam, namun Sapto seolah memberikan gambaran bahwa tidak hanya Islam yang memiliki kelompok keagamaan tetapi juga agama lain, namun teroris selalu diarahkan kepada Islam saja.

Penggunaan kemujaradan tahap buntu (deal level abstracting) seperti contoh Sabili menggunakan kalimat 'ketiga nama yang di tahan itu, menurut polisi di duga mendanai kelompok teroris Al-Qaidah Indonesia wilayah Serambi Mekkah'. 'Teroris Al-qaidah' merupakan istilah yang tidak dapat diartikan dengan makna sebenarnya karena tidak ada makna terhadap frasa tersebut. Pengunaan tahap abstrak yang tinggi ini akan membuat image Islam menjadi negatif.

Selanjutnya penggunaan tanda strip, seperti kalimat yang menyebutkan polisi telah men-generalisir mereka yang pernah berjihad di Afghan dan Filipina Selatan sebagai jaringan teroris. Tanda strip yang digunakan pada kata 'men-generalisir' adalah untuk meningkatkan kesadaran wartawan dalam penggunaan istilah, 'general' berasal dari bahasa Inggris sehingga penggunaan tanda strip dianggap sesuai.

Dalam penggunaan sub-sub trikotomi pula, Sabili cenderung menggunakan pernyataan tanggapan tidak bersumber seperti dalam berita yang menyebutkan tidak ada kesan yang buruk bagi Amrozi, Ali Ghufron, Imam Samudra dan Dulmatin, mereka adalah orang yang dianggap teroris oleh sebahagian pihak. Wartawan juga menyebutkan bahwa pengeboman yang terjadi selama ini adalah rancangan pihak yang tidak suka kepada Islam serta timbulnya ketidakadilan kepada pihak Islam dalam penanganan terorisme yang tidak sesuai aturan hukum. Selanjutnya berita yang menyatakan bahwa Pemerintah SBY punya kepentingan pada program war and terror, meskipun aktivis Islam yang disalahkan maka tidak mengherankan jika Densus 88 menyalahkan umat Islam karena dana yang diperoleh selama ini adalah dari pihak yang tidak suka kepada Islam. Pernyataan tanggapan tidak 
bersumber ini merupakan usaha wartawan dalam memberikan Image positif kepada aktivis-aktivis Islam yang dianggap sebagai teroris.

Pada pernyataan tanggapan bersumber pula, Sabili merujuk sumber berita dari pihak-pihak yang ingin membela aktivis Islam yang selama ini dianggap sebagai teroris. Seperti pernyataan tanggapan yang nyatakan oleh DR Mu'inuddin bahwa polisi sering menembak mati tersangka teroris tanpa bukti yang kuat.Ia juga menyebutkan bahwa pemerintah harus bijak dalam perkara ini sehingga tidak merugikan putera bangsa. Selanjutnya Munarman dan ketua MMI secara bersamaan menyatakan bahwa isu teroris selama ini hanya rencana pihak yang tidak suka pada Islam. Munarman juga menambahkan bahwa Sofyan adalah penyusup agar teroris dapat dijaga dan terus akan ada dan selama ini Amerika melakukan kampanye anti terror untuk memerangi Islam. Sekjen FUI juga menyebutkan kepada pihak polisi agar tidak marah di label thaghut karena cara mereka yang salah. Dari contoh-contoh pernyataan diatas dapat diketahui bahwa adanya usaha pembelaan bagi aktivis Islam yang selama ini dianggap sebagai teroris.

Dari pernyataan laporan bersumber pula dapat dilihat pada contoh berita Fauzan membandingkan hukuman bagi teroris dan pelaku korupsi yang tidak adil. Ustad Abu mengatakan bahwa aksi teroris yang dituduhkan tidak ada hubungannya dengan aktivitas di Aceh. Kemudian Abu Bakar juga menyatakan pihak polisi ingin mengaitkan dirinya dengan aktivitas di Aceh. Sapto juga menyatakan kalau dulu MMI kini Jamaah Ansharut Tauhid yang menjadi tersangka teroris, namun Laskar Kristus dan lainnya tidak menjadi tersangka teroris. Ketua Densus 88 menyatakan jika ada hubungan antara teroris Pamulang dan Aceh. Bambang menyatakan bahwa pihak polisi disebut sebagai thaghud oleh para aktivis Islam. Berita yang dinyatakan dalam pernyataan laporan bersumber ini cenderung dari pihak yang membela aktivis Islam yang dihubungkan dengan aksi teroris yang terjadi selama ini.

Pada pernyataan hukuman bersumber Sabili mengutip pernyataan dari orang tua Ammar yang menyebutkan bahwa "putra kami bukan teroris tapi mujahid" pernyataan ini dapat memberikan pendapat kepada khalayak sememangnya Dulmatin adalah seorang mujahid. Meskipun kata ini positif, namun dapat digolongkan pada pernyataan hukuman karena sudah memberikan persetujuan dan sentimen sumber atas sesuatu perkara.

\section{KESIMPULAN}

Kajian ini menggunakan analisis sub-sub kategori trikotomi yang diperkenalkan oleh Mohd Rajib Ab Ghani (1984) dari sudut semantik umum, untuk melihat bagaimana pemberitaan teroris dalam majalah Tempo dan Sabili terhadap image Islam. Dari kajian ini didapati bahwa Tempo cenderung menggunakan sumber berita yang diambil dari beberapa pihak yang tidak memihak kepada Islam sehingga menyebabkan image Islam negatif sedangkan Sabili berusaha untuk memperbaiki image Islam dengan menggunakan pernyataan tanggapan bersumber dari pihak yang ingin membela Islam. Kedua-dua majalah ini cenderung menggunakan pernyataan tanggapan tidak bersumber dalam penggunaan subsub kategori trikotomi dari sudut semantik umum.

\section{DAFTAR PUSTAKA}

Adnan Hussein. 1999. Bukan Semua Yang boleh Dikira Bermakna, Bukan Semua Yang Bermakna Boleh Dikira. Dalam Syed Arabi Idid. Analisis Kandungan. Bangi: Universiti Kebangsaan Malaysia.

Arpan Floyd G. (1964) Toward Better Communication. Kuala Lumpur: United Stated Information Service. 
Hayakawa, S.I. 1940. Language in Thought and Action. New York: Harcourt Brace Jovanovich Inc, Ed ke 4.

Heri Budiyanto. 2006. Perspektif Pemberitaan Tentang Teroris di Indonesia (analisis

Jos Daniel Parera. 1990. Teori Semantik. Jakarta: Erlangga.

Korzybski A. 1958. Science and Sanity: An Introduction to Non-Aristotalian System and General Semantics. USA: The Colonial Press Inc.

Martin, L.G \& Chaudary A.G.1983. Comparative Mass Media System: USA.Longman Inc.

Mohd Rajib Ab Ghani et al. 2000. Falsafah Semantik Umum dalam Objektiviti Kewartawanan Etika Kewartawanan. Dlm. Faridah Ibrahim \& Mus Chairil Samani (pnyt). Etika Kewartawanan. Ed ke 2. Hlm 164-179: Subang Jaya F.A.R Publisher.

Mohd Rajib Ab. 1984. Semantic Analysis of objectivity in two Malaysia News Paper. Dalam Faridah Ibrahim \& Chau Pao Ling. 1997. Analisis Semantik Objektifiti Citra Ahli Politik Wanita Tempatan. Jurnal Komunikasi. Jilid 13\&14, P: 73.

Mohd.Rajib Ab Ghani \& Faridah Ibrahim.2000. Objektiviti Bahasa dalam kewartawanan. Dlm.Faridah Ibrahim \& Mus Chairil Samani (pnyt). Etika kewartawanan. Ed ke 2. Hlm 117-127, Subang Jaya: F.A.R Publisher.

Nasir Abas. 2009. Memberantas Terorisme Memburu Noor Din M Top. Jakarta: Grafindo.

Stuart Chase. 1954. Power of Words. New York. Harcourt Brace \& World Inc. Wacana Komparasi di Harian Umum Republika dan Kompas. Buletin 